\title{
Characterization of Late-Onset Citrullinemia 1 in a Korean Patient: Confirmation by Argininosuccinate Synthetase Gene Mutation Analysis
}

\author{
In-Suk Kim², Chang-Seok Ki ${ }^{1}$, Jong-Won Kim', Munhyang Lee ${ }^{3}$, Dong-Kyu $\mathrm{Jin}^{3}$ and Soo-Youn Lee ${ }^{1, *}$ \\ ${ }^{1}$ Department of Laboratory Medicine, Samsung Medical Center, Sungkyunkwan University School of Medicine, Seoul 135-710, Korea \\ ${ }^{2}$ Department of Laboratory Medicine, Gyeongsang National University School of Medicine, Jinju 660-701, Korea \\ ${ }^{3}$ Department of Pediatrics, Samsung Medical Center, Sungkyunkwan University School of Medicine, Seoul 135-710, Korea
}

Received 1 February 2006, Accepted 6 April 2006

\begin{abstract}
A 16-month old boy was referred to our hospital for evaluation of recurrent generalized tonic clonic seizures. Metabolic evaluation revealed significant hyperammonemia $(1,112 \mu \mathrm{g} / \mathrm{dl})$. Amino acid/acylcarnitine screening using tandem mass spectrometry showed markedly increased plasma levels of citrulline $(1,350 \mu \mathrm{M} / \mathrm{l})$ with undetectable levels of arginine and arginosuccinic acid. Urinary excretion of citrulline was markedly increased $(38,617 \mu \mathrm{M}$ / g creatinine). Brain MRI findings showed diffuse highsignal intensity lesions, that involved gray and white matter in both frontal lobes and insula with edematous changes; these findings were consistent with the acute stage of citrullinemia (CTLN). Mutation analysis of the argininosuccinate synthetase ( $A S S$ ) gene, in this patient, showed a Gly324Ser mutation in exon 13, and a 67-bp duplication mutation in exon 15 (c.1128-6_1188dup67). The patient was confirmed as having late-onset CTLN1 and treated with anticonvulsants, lactulose enema, protein restricted diet and arginine. Here we describe a case of late-onset CTLN1 in a patient by biochemical analyses and ASS gene mutation confirmation. This is the first report of a Korean patient with late-onset CTLN1 confirmed by $A S S$ gene mutation identification.
\end{abstract}

Keywords: Argininosuccinate synthetase (ASS), Citrullinemia, Hyperammonemia, Mass spectrometry, Mutation, Korean

\section{Introduction}

Citrullinemia (CTLN), a rare autosomal recessive disorder, is characterized by the accumulation of citrulline and

\footnotetext{
* To whom correspondence should be addressed.

Tel: 82-2-3410-1834; Fax: 82-2-3410-2719

E-mail: sy117.lee@samsung.com
}

hyperammonemia caused by a deficiency in argininosuccinate synthetase (ASS), the third enzyme in the urea cycle that catalyzes the formation of argininosuccinate from citrulline and aspartate. Patients with CTLN have been classified, biochemically, into three groups: type I, type II and type III on the basis of residual ASS activity, enzyme kinetics and tissue specificity of enzyme deficiency (Saheki et al., 1987). Following the recent report by Kobayashi et al., who identified the citrin gene responsible for adult-onset type II CTLN (Kobayashi et al., 1999), CTLN is now classified as CTLN1 (type I and type III: OMIM \#215700, abnormality in ASS gene) and CTLN2 (type II CTLN: OMIM \#603471, abnormality in SLC25A13 gene) according to the molecular pathogenesis.

CTLN1 is caused by a mutation in the ASS gene located on chromosome 9q34. CTLN1 presents as a clinical spectrum that includes: a neonatal acute form (the "classic" form), a milder late-onset form, a form with onset of symptoms during pregnancy or postpartum, and a form without symptoms or hyperammonemia (Wick et al., 1973). Most patients with classical CTLN1 present with symptoms during the early neonatal period that include acute hyperammonemia and lifethreatening encephalopathy. In other patients, with the milder late-onset type, the disease becomes manifest only later in infancy or in childhood; these patients may have prolonged survival with mental retardation, intermittent ataxia, and abnormalities of hair and skin (Whelan et al., 1976). Women with onset of severe symptoms during pregnancy, or in the postpartum period, have been reported (Gao et al., 2003). Individuals remaining asymptomatic up to at least ten years of age have been reported; it seems possible that they may remain asymptomatic throughout life (Haberle et al., 2002; Haberle et al., 2003).

CTLN2 is caused by citrin deficiency resulting from mutations in SLC25A13 on chromosome 7q21.3, which encodes the mitochondrial solute carrier protein, citrin. Citrin deficiency leads to a failure to shuttle aspartate and glutamate to and from the mitochondrion, leading to a mild 


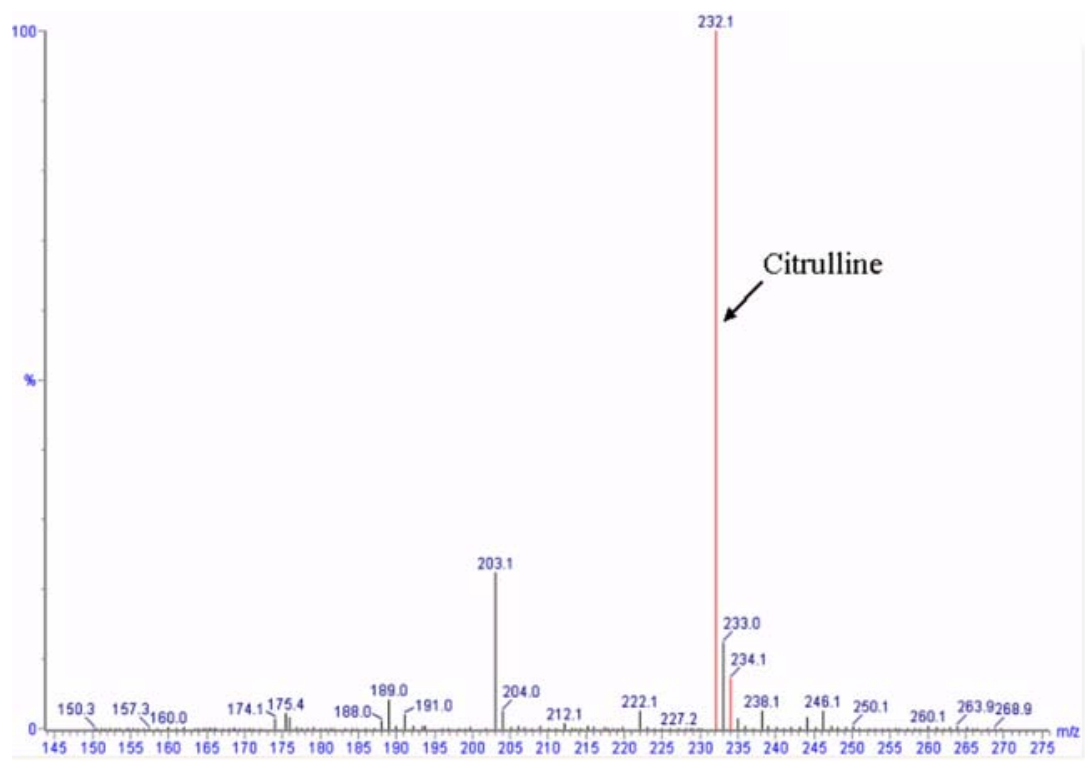

Fig. 1. Spectrum of the sample from this patient with citrullinemia showing a significant increase in citrulline.

hyperammonemia and CTLN (Iijima et al., 2001). CTLN2 is characterized by a less pronounced elevation of plasma citrulline and late-onset of clinical symptoms. Affected patients present most commonly with neurological symptoms such as disturbed consciousness, restlessness, and coma that are secondary to chronic cerebral edema. Recently, neonatal presentation of CTLN2 has been reported (Ohura et al., 2001).

Distinction between the clinical forms of CTLN is based on clinical findings; however, they may not be clear-cut. We describe a case of late-onset CTLN1 confirmed by biochemical analyses and $A S S$ gene mutation analysis; this is the first report of a late-onset case of CTLN1 in Korea.

\section{Case report}

This male infant is the first child of nonconsanguineous healthy parents. He was born at 40 weeks gestational age by normal spontaneous vaginal delivery. His birth weight was 3,018 g, and Apgar scores were 9 at $1 \mathrm{~min}$ and 10 at $5 \mathrm{~min}$. The neonatal period was unremarkable. No specific family history was noted except for a history of hypertension in a grandmother.

At the age of 16 months, he was admitted to a secondary care hospital with recurrent generalized tonic clonic seizures (GTCs) and cyclic vomiting for about 10 days; he was referred to an intensive care unit at a tertiary care hospital. The physical examination was significant for: hypotonia, arm rigidity, ankle clonus and developmental delay. His height and weight were at the $10^{\text {th }}$ and $3^{\text {rd }}$ percentile, respectively. Markedly increased plasma ammonia levels were noted $(1,112 \mu \mathrm{g} / \mathrm{dl}$, normal range; 18 54). Amino acid/acylcarnitine screening using tandem mass spectrometry (MS/MS) was performed. The results of MS/MS showed markedly increased
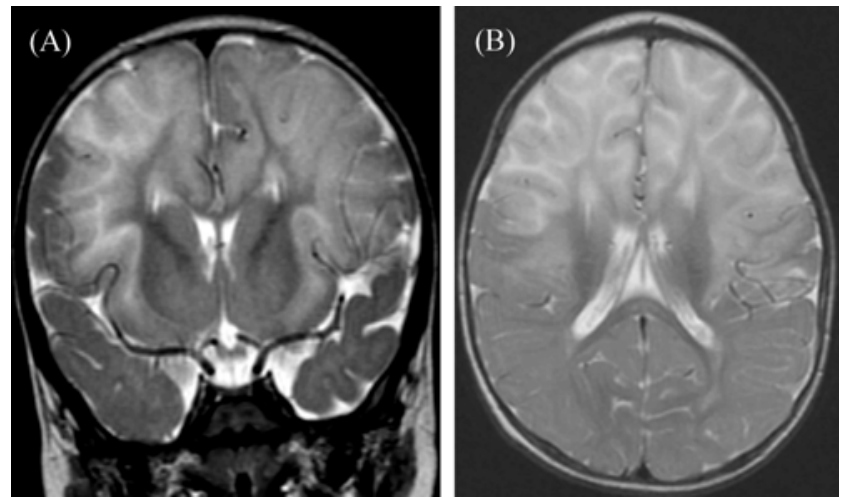

Fig. 2. Brain MRI findings showed diffuse high-signal intensity lesions involving gray and white matter in both the frontal lobes and insula with edematous changes. (A) axial T2 weighted image, (B) coronal T2 weighted image.

plasma level of citrulline $(1,350 \mu \mathrm{M} / 1$, cut-off $<52)$ with undetectable levels of arginine and arginosuccinic acid (Fig. 1). Plasma amino acid analysis by high performance liquid chromatography (HPLC) showed a high citrulline level (1,709 $\mathrm{pM} / \mu 1$, normal range; 3 35) and a low normal arginine level (42.6 pM/ $\mu 1$, normal range; 12 133). A markedly increased urinary excretion of citrulline $(38,617 \mu \mathrm{M} / \mathrm{g}$ creatinine, normal range 22 180) was noted on urinary amino acid analysis. Urinary organic acid analysis by GC/MS showed increased urinary orotic acid excretion $(297.15 \mathrm{mM} / \mathrm{M}$ creatinine, normal range; $0 \sim 7.64$ ). The brain MRI revealed diffuse high-signal intensity lesions involving gray and white matter in both the frontal lobes and insula with edematous changes (Fig. 2). These findings were consistent with the acute stage of CTLN. Electroencephalography (EEG) showed no specific findings. 
(A)

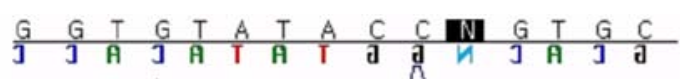

Patient

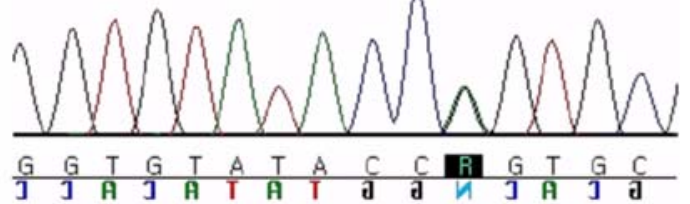

Father

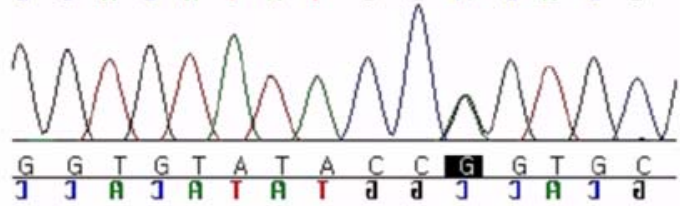

Mother

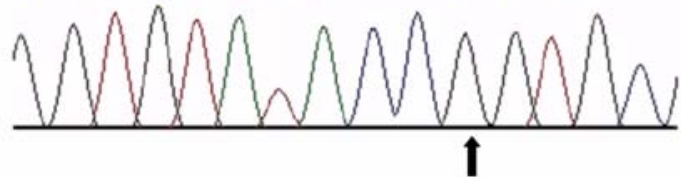

(B)

Patient

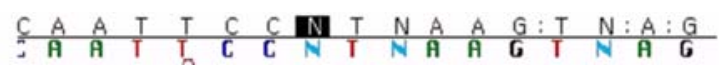

Patient
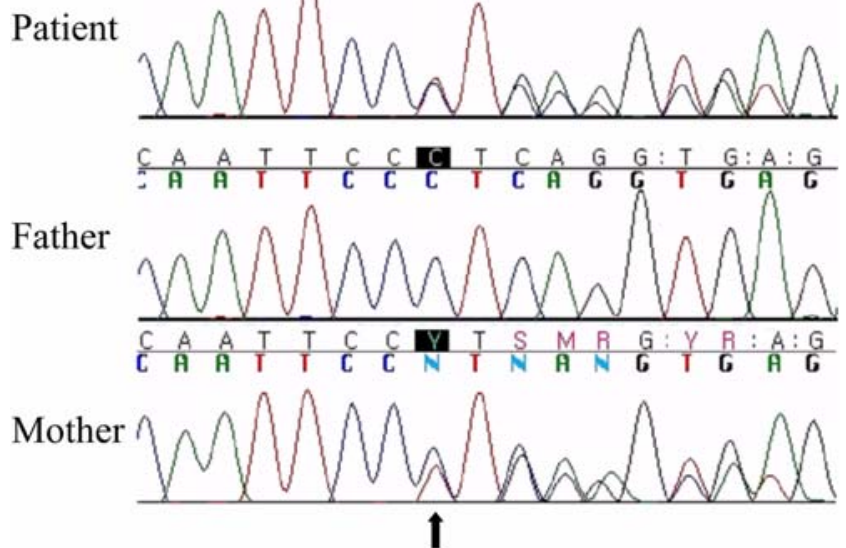

Fig. 3. Argininosuccinate synthetase gene mutation analysis showed Gly324Ser mutation in exon 13 and 67-bp duplication mutation in exon 15. Gly324Ser mutation was observed in the patient and his father and 67-bp duplication mutation was noted in the patient and his mother. (A. c.970G $>$ A (p.Gly324Ser) mutation in the patient and his father, B. 67-bp duplication mutation in exon 15 (c.1128-6_1188dup67) in the patient and his mother).

We collected blood for DNA analysis from the patient and his parents. Mutation analysis using PCR, and direct sequencing of all exons and adjacent introns of the ASS gene were performed. The patient had a Gly324Ser mutation in exon 13 and a 67-bp duplication mutation (c.1128-6 1188 dup67) in exon 15. The father had the Gly324Ser mutation, and the mother had the 67-bp duplication mutation in exon 15 (Fig. 3). Based on these studies, the diagnosis of late-onset CTLN1 was confirmed.

After treatment with a lactulose enema (6 times/d), the blood ammonia level decreased gradually to $649 \mu \mathrm{g} / \mathrm{dl}$ on the first day, $232 \mu \mathrm{g} / \mathrm{dl}$ on the second day, $178 \mu \mathrm{g} / \mathrm{dl}$ on the third day, and $146 \mu \mathrm{g} / \mathrm{dl}$ on the fourth day of treatment. His seizures (GTCs, 8-20 min of duration, 2 4 times/d) continued for 11 days despite aggressive anticonvulsant therapy and a decreased ammonia level. After 5 days of treatment, a diffusionweighted MRI showed new findings of high-signal intensity in gray matter at the left parietal lobe with an apparent decreased diffusion coefficient. This identified brain damage was considered to be irreversible. The patient was also treated with a protein restricted diet and arginine; he received rehabilitation management for rigidity of the extremities. After 1 month, the extremities had improved movement, and the plasma ammonia and citrulline levels were markedly decreased to $105 \mu \mathrm{g} / \mathrm{dl}$ and $524 \mathrm{pM} / 1$, respectively. However, progressive tissue loss of both frontal lobes, on brain MRI, was noted.

\section{Discussion}

Classical neonatal-onset CTLN1 is suspected in infants on a normal unrestricted protein diet, and who present in the first week of life with: hyperammonemia resulting in increasing lethargy, somnolence, refusal to feed, vomiting, and tachypnea; or increased intracranial pressure (secondary to hyperammonemia) resulting in: increased neuromuscular tone, spasticity, ankle clonus seizures, loss of consciousness, and death (Bachmann, 2003a; Bachmann, 2003b). Fifty-six percent of individuals with classic CTLN1 are symptomatic within four days of age, and $67 \%$ within one week of age (Bachmann, 2003a). The longest reported survival of an untreated infant with classic CTLN1 was 17 days (Thoene et al., 1977). Late-onset CTLN1 is suspected in individuals with recurrent lethargy, somnolence, mental retardation, and chronic or recurrent hyperammonemia. When episodes of hyperammonemia occur, the findings are similar to those seen in the acute neonatal form; however, the neurologic findings may be more subtle because of the older age of affected individuals. The symptoms of hyperammonemia are often non-specific, and may not be recognized by the family or primary care physician in a timely manner for early intervention. Patients with CTLN2 show hyperammonemia and neuropsychiatic symptoms such as: disorientation, delirium, aberrant behavior, delusion, and disturbance of consciousness, often leading rapidly to death (Kobayashi et al., 1995). The onset is sudden, usually between the ages of 20 and 40 years (Ikeda et al., 2001). Although the prognosis is generally poor, liver transplantation can be remarkably effective (Kawamoto et al., 1997; Ikeda et al., 2001). Generally, the clinical course of individuals with CTLN2 is milder than CTLN1, frequently distinguishing it from lateonset CTLN1. It is unclear why CTLN2 has milder symptoms and later onset than late-onset CTLN1; distinguishing between these two disorders can be difficult.

The diagnostic findings in the patient described here were consistent with CTLN. The detection of a mutation in the ASS gene, the biochemical profile and the presenting symptoms excluded CTLN2 derived from citrin deficiency. Molecular 
Table 1. Reported citrullinemia in Korea

\begin{tabular}{|c|c|c|c|c|c|c|c|c|}
\hline $\begin{array}{l}\text { Case } \\
\text { number }\end{array}$ & $\begin{array}{c}\text { Year } \\
\text { reported }\end{array}$ & $\begin{array}{l}\text { Onset of } \\
\text { symptoms }\end{array}$ & Initial symptoms & $\begin{array}{l}\text { Highest } \\
\text { citrulline level }\end{array}$ & $\begin{array}{c}\text { Highest } \\
\text { ammonia } \\
\text { level }\end{array}$ & $\begin{array}{c}\text { Molecular test of } A S S \\
\text { gene }\end{array}$ & Outcome & Reference \\
\hline 1 & 1987 & 26-day-old & $\begin{array}{l}\text { Vomiting, seizure, } \\
\text { coma }\end{array}$ & $\begin{array}{c}3,150 \mu \mathrm{M} / 1 \\
\text { (normal range: } 20-50 \text { ) }\end{array}$ & $500 \mu \mathrm{g} / \mathrm{dl}$ & NT & $\begin{array}{l}\text { Neuro- } \\
\text { logic defi- } \\
\text { cit }\end{array}$ & $\begin{array}{c}\text { (Kim et } \\
\text { al., 1987) }\end{array}$ \\
\hline 2 & 1995 & 3-day-old & $\begin{array}{c}\text { Dyspnea, seizure, } \\
\text { coma }\end{array}$ & $\begin{array}{c}571 \mu \mathrm{M} / 1 \\
\text { (normal range: } 13-42 \text { ) }\end{array}$ & $737 \mu \mathrm{g} / \mathrm{dl}$ & NT & Death & $\begin{array}{l}\text { (Park et } \\
\text { al., 1995) }\end{array}$ \\
\hline 3 & 1997 & 3-day-old & $\begin{array}{l}\text { Lethargy, seizure, } \\
\text { coma }\end{array}$ & $\begin{array}{c}2,599 \mu \mathrm{M} / 1 \\
\text { (normal range: } 0-13 \text { ) }\end{array}$ & $400 \mu \mathrm{g} / \mathrm{dl}$ & NT & Death & $\begin{array}{c}\text { (Park et } \\
\text { al., 1997) }\end{array}$ \\
\hline 4 & 1999 & $\begin{array}{l}\text { 3-month- } \\
\text { old }\end{array}$ & Convulsions & $\begin{array}{c}2,401 \mu \mathrm{M} / 1 \\
\text { (normal range: } 3-35 \text { ) }\end{array}$ & $400 \mu \mathrm{g} / \mathrm{dl}$ & NT & $\begin{array}{l}\text { Neuro- } \\
\text { logic defi- } \\
\text { cit }\end{array}$ & $\begin{array}{l}\text { (Kim et } \\
\text { al., 1999) }\end{array}$ \\
\hline 5 & 1999 & 53-day-old & $\begin{array}{l}\text { Convulsions, } \\
\text { drowsy mentality }\end{array}$ & $\begin{array}{c}1,376 \mu \mathrm{M} / 1 \\
\text { (normal range: } 3-35 \text { ) }\end{array}$ & $535 \mu \mathrm{g} / \mathrm{dl}$ & NT & Death & $\begin{array}{l}\text { (Kim et } \\
\text { al., 1999) }\end{array}$ \\
\hline 6 & 1999 & 9-day-old & $\begin{array}{l}\text { Feeding difficulty, } \\
\text { lethargy }\end{array}$ & $\begin{array}{l}4,178 \mu \mathrm{M} / 1 \\
\text { (normal range: } 13.8-41.6 \text { ) }\end{array}$ & $400 \mu \mathrm{g} / \mathrm{dl}$ & NT & $\begin{array}{l}\text { Neuro- } \\
\text { logic defi- } \\
\text { cit }\end{array}$ & $\begin{array}{l}\text { (Jeong et } \\
\text { al., 1999) }\end{array}$ \\
\hline 7 & 2000 & $\begin{array}{c}\text { Not } \\
\text { described }\end{array}$ & Not described & Not described & $\begin{array}{c}\text { Not } \\
\text { described }\end{array}$ & $\begin{array}{l}\text { [p.Gly324Ser]+ } \\
\text { [c. IVS6-2A>G] }\end{array}$ & Death & $\begin{array}{l}\text { (Hong et } \\
\text { al., 2000c) }\end{array}$ \\
\hline 8 & 2000 & $\begin{array}{c}\text { Not } \\
\text { described }\end{array}$ & Not described & Not described & $\begin{array}{c}\text { Not } \\
\text { described }\end{array}$ & $\begin{array}{c}\text { [c.1128- } \\
\text { 6_1188dup67]+ } \\
\text { [c. IVS6-2A>G] }\end{array}$ & Death & $\begin{array}{l}\text { (Hong et } \\
\text { al., 2000c) }\end{array}$ \\
\hline 9 & 2000 & $\begin{array}{c}\text { Not } \\
\text { described }\end{array}$ & Not described & Not described & $\begin{array}{c}\text { Not } \\
\text { described }\end{array}$ & $\begin{array}{l}\text { [p.Gly324Ser]+ } \\
\text { [c. IVS6-2A>G] }\end{array}$ & $\begin{array}{l}\text { Neuro- } \\
\text { logic defi- } \\
\text { cit }\end{array}$ & $\begin{array}{l}\text { (Hong et } \\
\text { al., 2000c) }\end{array}$ \\
\hline 10 & 2002 & 3-day-old & Drowsy mentality & $\begin{array}{c}680 \mu \mathrm{M} / 1 \\
\text { (normal range: } 13-42 \text { ) }\end{array}$ & $\begin{array}{c}1,708 \mu \mathrm{g} / \\
\mathrm{dl}\end{array}$ & NT & Death & $\begin{array}{l}\text { (Song et } \\
\text { al., 2002) }\end{array}$ \\
\hline 11 & 2002 & 55-year-old & $\begin{array}{c}\text { Generalized } \\
\text { weakness, insomia }\end{array}$ & $\begin{array}{c}3,958 \mu \mathrm{M} / 1 \\
\text { (normal range: } 15-50.5 \text { ) }\end{array}$ & $427 \mu \mathrm{g} / \mathrm{dl}$ & NT & $\begin{array}{l}\text { Neuro- } \\
\text { logic defi- } \\
\text { cit }\end{array}$ & $\begin{array}{l}\text { (Park et } \\
\text { al., 2002) }\end{array}$ \\
\hline 12 & 2006 & $\begin{array}{l}\text { 16-month- } \\
\text { old }\end{array}$ & Seizure, vomiting & $\begin{array}{c}1,709 \mu \mathrm{M} / 1 \\
\text { (normal range: } 3-35 \text { ) }\end{array}$ & $1,112 \mu \mathrm{g} / \mathrm{dl}$ & $\begin{array}{c}\text { [p.Gly324Ser]+ } \\
{[\text { c.1128-6_1188dup67] }}\end{array}$ & $\begin{array}{l}\text { Neuro- } \\
\text { logic defi- } \\
\text { cit }\end{array}$ & This case \\
\hline
\end{tabular}

Abbreviations: ASS, argininosuccinate synthetase gene; NT, not tested.

investigation of the $A S S$ gene helped reach the definitive diagnosis of late-onset CNLN1. This case was distinguished by the relative late-onset of the initial presentation at 16 months, compared to other reported cases of CTLN in Korea (Table 1). Most prior cases suggested an acute-neonatal onset of CTLN1 except for one patient who presented at 55 years of age with suspected CTLN2 (Park et al., 2002). Sixty percent of reported CTLN1 cases (6/10) had early mortality and the rest suffered from severe neurological sequela. After introduction of pharmacological therapy, the clinical outcome for CTLN has improved, and now depends on the degree of hyperammonemia at the start of effective treatment. This is the first report of a case of late-onset CTLN1, not acute neonatal onset CTLN1, in Korea.

Approximately 31,000 newborns and high risk infants have been tested, as a result of the newborn screening program, using MS/MS at a commercial laboratory center in Korea, and 28 infants $(0.09 \%)$ were confirmed to have an inborn error of metabolism (Yun et al., 2003). Of the 28 infants, only one
$(0.003 \%)$ infant was reported to have CTLN. The screening results allow for the introduction of immediate specific treatment for CTLN, and may have prevented metabolic decompensation in newborns with presumed mild CTLN1. Although the incidence of CTLN is very low in Korea, MS/ MS screening, for CTLN, may improve the cost per qualityadjusted life years saved by mass screening programs.

CTLNI is inherited in an autosomal recessive manner. The parents of an affected child are obligate heterozygotes and asymptomatic carriers. Therefore mutation analysis is the method required for confirmation of a definite diagnosis in affected patients, carrier detection in parents and prenatal diagnosis for subsequent pregnancies. Currently there are 58 different $A S S$ gene mutations: seven deletion, four splice site, two duplication, two nonsense and 43 missense that have been identified. Three mutations are particularly frequent: IVS62A > G, Gly390Arg, and Arg304Trp (Gao et al., 2003). Most of the described mutations, in the ASS gene, are missense mutations; however, patients have highly variable clinical 
courses. The clinical course of patients with truncated mutations or the Gly390Arg mutation generally is the earlyonset/severe presentation. In mutation analyses performed on three Korean patients with CTLN, all three patients were compound heterozygotes (Hong et al., 2000c). They had splice mutation IVS6-2A $>\mathrm{G}$; two of the patients had a Gly324Ser mutation in exon 13, and one had a 67-bp duplication mutation in exon 15 (c.1128-6_1188dup67). Molecular prenatal diagnosis has been successfully performed for a family with CTLN1 in Korea (Hong et al., 2000b). In the current case presented the patient was compound heterozygotes. As might be expected, for asymptomatic carriers, his parents each had a different mutant allele. One mutant allele inherited from his father was the Gly324Ser mutation, and the other from his mother was the 67-bp duplication mutation in exon 15. The missense mutation, Gly324Ser (substitution of serine (AGT) for glycin (GGT)), involved conversion of a $\mathrm{CpG}$ dinucleotide in the sense strand to $\mathrm{CpA}$, has already been described in patients with the classical form of CTLN (Kobayashi et al., 1990; Hong et al., 2000c; Gao et al., 2003) with a mild clinical course (Haberle et al., 2003). The 67-bp duplication mutation in exon 15, duplication of 67-bp (from -6 of intron 14 to 5 '-side 61 -bp of exon 15) causes a frameshift in exon 15 leading to premature termination. This mutation has been reported previously in one Korean patient with CTLN1 that typically presents with hyperammonemia, metabolic coma, mental retardation, and/or early death (Hong et al., 2000a; Hong et al., 2000c). It continues to be difficult to show a genotype-phenotype correlation, because many patients have been compound heterozygotes, from different environments at the time of diagnosis, and/or had several different treatment regimes at various stages of disease. Although a limited number of Korean patients have been studied, the IVS6-2A $>$ G, Gly324Ser, 67-bp duplication mutation in exon 15 appears to be the most common mutation in the ASS gene found in Korea to date. Molecular investigation improves our understanding of the pathogenesis of CTLN by identifying the most frequent mutant alleles in Korean patients. In addition, availability of molecular prenatal diagnosis and carrier detection may help families prevent neurologic sequela and/or early death associated with CTLN.

In conclusion, we describe a case of late-onset CTLN1 confirmed by biochemical and $A S S$ gene mutation analysis. This is the first report of a patient with late-onset CTLN1, not acute neonatal onset CTLN1, in Korea. Therefore, this case report shows the importance of performing molecular investigations in order to reach a definitive diagnosis, particularly in cases of late-onset CTLN.

\section{References}

Bachmann, C. (2003a) Long-term outcome of patients with urea cycle disorders and the question of neonatal screening. Eur. $J$. Pediatr. 162, 29-33.
Bachmann, C. (2003b) Outcome and survival of 88 patients with urea cycle disorders: a retrospective evaluation. Eur. J. Pediatr. 162, 410-416.

Gao, H. Z., Kobayashi, K., Tabata, A., Tsuge, H., Iijima, M., Yasuda, T., Kalkanoglu, H. S., Dursun, A., Tokatli, A., Coskun, T., Trefz, F. K., Skladal, D., Mandel, H., Seidel, J., Kodama, S., Shirane, S., Ichida, T., Makino, S., Yoshino, M., Kang, J. H., Mizuguchi, M., Barshop, B. A., Fuchinoue, S., Seneca, S., Zeesman, S., Knerr, I., Rodes, M., Wasant, P., Yoshida, I., De Meirleir, L., Abdul Jalil, M., Begum, L., Horiuchi, M., Katunuma, N., Nakagawa, S. and Saheki, T. (2003) Identification of 16 novel mutations in the argininosuccinate synthetase gene and genotype-phenotype correlation in 38 classical citrullinemia patients. Hum. Mutat. 22, 24-34.

Haberle, J., Pauli, S., Linnebank, M., Kleijer, W. J., Bakker, H. D., Wanders, R. J., Harms, E. and Koch, H. G. (2002) Structure of the human argininosuccinate synthetase gene and an improved system for molecular diagnostics in patients with classical and mild citrullinemia. Hum. Genet. 110, 327-333.

Haberle, J., Pauli, S., Schmidt, E., Schulze-Eilfing, B., Berning, C. and Koch, H. G. (2003) Mild citrullinemia in Caucasians is an allelic variant of argininosuccinate synthetase deficiency (citrullinemia type 1). Mol. Genet. Metab. 80, 302-306.

Hong, K. M., Hahn, S. H. and Paik, M. K. (2000a) Novel 67-bp insertional mutation in the $A S S$ gene in a patient with citrullinemia. Hum. Mutat. 15, 585.

Hong, K. M., Paik, M. K., Yoo, O. J. and Hahn, S. H. (2000b) The first successful prenatal diagnosis on a Korean family with citrullinemia. Mol. Cells 10, 692-694.

Hong, K. M., Shin, C. H., Choi, Y. B., Song, W. K., Lee, S. D., Rhee, K. I., Jang, P., Pak, G. S., Kim, J. K., Paik, M. K. and Hahn, S. H. (2000c) Mutation analysis of Korean patients with citrullinemia. Mol. Cells 10, 465-468.

Iijima, M., Jalil, A., Begum, L., Yasuda, T., Yamaguchi, N., Xian Li, M., Kawada, N., Endou, H., Kobayashi, K. and Saheki, T. (2001) Pathogenesis of adult-onset type II citrullinemia caused by deficiency of citrin, a mitochondrial solute carrier protein: tissue and subcellular localization of citrin. Adv. Enzyme Regul. 41, 325-342.

Ikeda, S., Yazaki, M., Takei, Y., Ikegami, T., Hashikura, Y., Kawasaki, S., Iwai, M., Kobayashi, K. and Saheki, T. (2001) Type II (adult onset) citrullinaemia: clinical pictures and the therapeutic effect of liver transplantation. J. Neurol. Neurosurg. Psychiatry 71, 663-670.

Jeong, E., Chun, S. and Seo, S. (1999) A case of citrullinemia controlled by diet and arginine. J. Korean Soc. Neonatol. 6, 280-284.

Kawamoto, S., Strong, R. W., Kerlin, P., Lynch, S. V., Steadman, C., Kobayashi, K., Nakagawa, S., Matsunami, H., Akatsu, T. and Saheki, T. (1997) Orthotopic liver transplantation for adultonset type II citrullinaemia. Clin. Transplant. 11, 453-458.

Kim, B., Bang, H., Lee, D., Lee, S. and Chung, M. (1987) A case of citrullinemia. J. Korean Pediatr. Soc. 30, 794-804.

Kim, H., Kim, J., Bae, S., Yoon, C. and Yoo, H. (1999) Two cases of citrullinemia presented with strokes. J. Korean Pediatr. Soc. 42, 437-441.

Kobayashi, K., Bang, L. Y., Xian, L. M., Nishi, I., Hsiao, K. J., Choeh, K., Yang, Y., Hwu, W. L., Reichardt, J. K., Palmieri, F., Okano, Y. and Saheki, T. (2003) Screening of nine SLC25A13 mutations: their frequency in patients with citrin 
deficiency and high carrier rates in Asian populations. Mol. Genet. Metab. 80, 356-359.

Kobayashi, K., Jackson, M. J., Tick, D. B., O'Brien, W. E. and Beaudet, A. L. (1990) Heterogeneity of mutations in argininosuccinate synthetase causing human citrullinemia. $J$. Biol. Chem. 265, 11361-11367.

Kobayashi, K., Kakinoki, H., Fukushige, T., Shaheen, N., Terazono, H. and Saheki, T. (1995) Nature and frequency of mutations in the argininosuccinate synthetase gene that cause classical citrullinemia. Hum. Genet. 96, 454-463.

Kobayashi, K., Sinasac, D. S., Iijima, M., Boright, A. P., Begum, L., Lee, J. R., Yasuda, T., Ikeda, S., Hirano, R., Terazono, H., Crackower, M. A., Kondo, I., Tsui, L. C., Scherer, S. W. and Saheki, T. (1999) The gene mutated in adult-onset type II citrullinaemia encodes a putative mitochondrial carrier protein. Nat. Genet. 22, 159-163.

Ohura, T., Kobayashi, K., Tazawa, Y., Nishi, I., Abukawa, D., Sakamoto, O., linuma, K., and Saheki, T. (2001) Neonatal presentation of adult-onset type II citrullinemia. Hum. Genet. 108, 87-90.

Park, B., Lee, D., Choi, J. and Jung, H. (1995) A case of citrullinemia. J. Korean Soc. Neonatol. 2, 248-252.

Park, D., Ki, D., Moon, S. and Lee, I. (1997) A case of citrullinemia. J. Korean Pediatr. Soc. 40, 584-592.

Park, H., Lim, H., Jung, I., Kim, Y., Kim, I., Chung, I., Kim, H., Park, S., Lee, M., Kim, S. and Lee, D. (2002) A case of adulttype citrullinemia with hyperammonemia. Korean $J$. Gastroenterol. 39, 379-385.
Ruitenbeek, W., Kobayashi, K., Iijima, M., Smeitink, J. A., Engelke, U. F., De Abreu, R. A., Kwast, H. T., Saheki, T., Boelen, C. A., De Jong, J. G. and Wevers, R. A. (2003) Moderate citrullinaemia without hyperammonaemia in a child with mutated and deficient argininosuccinate synthetase. Ann. Clin. Biochem. 40, 102-107.

Saheki, T., Kobayashi, K., Ichiki, H., Matuo, S., Tatsuno, M., Imamura, Y., Inoue, I., Noda, T. and Hagihara, S. (1987) Molecular basis of enzyme abnormalities in urea cycle disorders. With special reference to citrullinemia and argininosuccinic aciduria. Enzyme 38, 227-232.

Song, S., Oh, K., Hong, M., Kim, H., Shin, H., Kim, S. and Chang, J. (2002) A case of citrullinemia diagnosed at the neonatal period. J. Korean Pediatr. Soc. 45, 524-528.

Thoene, J., Batshaw, M., Spector, E., Kulovich, S., Brusilow, S., Walser, M. and Nyhan, W. (1977) Neonatal citrllinemia: treatment with keto-analogues of essential amino acids. $J$. Pediatr. 90, 218-224.

Whelan, D. T., Brusso, T. and Spate, M. (1976) Citrullinemia: phenotypic variations. Pediatrics 57, 935-941.

Wick, H., Bachmann, C., Baumgartner, R., Brechbuhler, T., Colombo, J. P., Wiesmann, U., Mihatsch, M. J. and Ohnacker, H. (1973) Variants of citrullinaemia. Arch. Dis. Child. 48, 636641.

Yun, H. K. L., Lee, D., Kang, S. and Ha, Y. (2003) Screening of newbrons and high risk infants for inherited metabolic disease by tandem mass spectrometry in Korea; 2 Years of the SCL Experience. Korean J. Lab. Med. 23, 517. 